\title{
Sonata of Jaroslav Ježek in the Context of the Composer's Work for the Piano
}

\author{
Václav Horák
}

I.

The piano Sonata is one of the major works of Jaroslav Ježek (1906-1942). This composition in four movements, written in 1939-1941 in his exile in the U.S.A., was the last work he finished. ${ }^{1}$ In the not very numerous studies of the composer, ${ }^{2}$ or in the synthetic works such as Dějiny české hudební kultury [History of Czech Music Culture], the Sonata is held to be unique, one of the peaks both of his work and the Czech music of the day. ${ }^{3}$

From The Second String Quartet (1940) only the first, sonata movement (Allegretto) has survived.

2 The existing literature on Jaroslav Ježek is mainly historiographical, with elements of the educational or publicistic style. So e.g. the most important monograph written by the lifelong promoter of Ježek's work, Václav Holzknecht, Jaroslav Ježek a Osvobozené divadlo [Jaroslav Ježek and the Liberated Theater] (Prague, 1957; Prague, 2006) and Jaroslav Ježek (Prague, 1982) present the composer's biography nearly as a piece of fiction. Biographical passages alternate with brief descriptions of his compositions but without any systematic musicological analysis and without the context of composing. These monographs, however, in spite of their popular character, are important because of their rich factual material, the work is conceived almost as a "chronicle", written by a direct participant of the events described in the book.

3 As a climax and from the aspect of composition and aesthetics a unique work the Sonata was also presented by Josef Bek and Oldřich Pukl: "The piano sonata is one of the most valuable works of this kind in Czech modern literature. It contains some elements of style which are new in Ježek: the themes are more compact, the piano sound [...] is softened there. In addition to the toccata and the figurative toccata stylization, known from earlier works by Ježek, the Sonata features a rich position of chords which gives better opportunity for more contrasting structures of the movements." In Robert Smetana (ed.), Dějiny české hudební kultury 1890/1945, Part 2 (1918-1945) (Prague, 1981), p. 266. Similarly Jaroslav Jiránek in his study “Česká klavírní tvorba 1890-1945” [Czech Works for the Piano 1890-1945], the material of which was adopted by the two volumes of the Déjiny české hudebni kultury conceives the Sonata as a composition "in which the composer's originally harsh constructivist style was substantially softened and modified by the obvious need for increased expressivity.” In Hudební věda [Musicology], 4 (1967), No. 2, p. 285. 
The Sonata is the last in the series of Ježek's piano compositions in the field of art music. They include, in chronological order: Suita pro čtvrttónový klavir [Suite for the quartertone piano] (1927), Sonatina (1928), Petite suite (1928), Capriccio (1932), ${ }^{4}$ Etude (1933), Bagatelles (1933), Rhapsodie [Rhapsody] (1938), Toccata (1939), Grande valse brillante (1939) and Sonata (1941).

The Sonata is important by the fact that the composer integrated into the four movements of a large, structured work his characteristic approaches noticeable already in his earlier compositions (in particular for the piano): e.g. the compact areas on the basis of a stream of figurations stylized as a toccata, the distinctive sharpening of the sound by means of dissonance (e.g. in present as well as in subsequent false-relations, tritones), ninth, eleventh or thirteenth chords produced by accumulating the thirds on the tones of especially the white keys, the melodic and rhythmic ostinato areas, the colourist use of the polarity of black and white keys, etc. In expression (and thus in the composition) of the Sonata, many features appear that crystallized already in the earlier development of the cycle of his sonatas. They are, in particular, the configurations of the dramatic, lyrical (or cantabile) and scherzo ${ }^{5}$ element produced or filled by means of the music of the first half of the $20^{\text {th }}$ century.

II.

The first movement of the Sonata is composed like the traditional cycle of sonatas, in the form of a sonata with the schema exposition (bars 1-52) - development (bars 53-127) recapitulation (bars 128-164). During the exposition, three basic themes are introduced, which differ in expression, tempo, dynamics and meter. They can be identified as principal, subordinate and concluding themes and from the characteristic features of the texture, differences between the themes can be established (either quick semiquaver passages or chord areas prevail). There areas are separated by figurative ${ }^{6}$ sections of music. Passages forming a variation of elements in the principal theme and a variation of the lyrical subordinate theme form the concluding part of the exposition (bars 38-52). In the development motifs are used from the principal and the concluding themes in an identical sequence and identifiable with the exposition. The extended moveable semiquaver passages are thus confronted and at the same time balanced by the (re-) introduction of more complex

4 Ježek performed his Capriccio on 27 October 1932 on the occasion of the opening of the surrealist exhibition Poetry 1932 in the Mánes Hall in Prague. However, he played from memory, the musical notation was not made. See Václav Holzknecht, Jaroslav Ježek a Osvobozené divadlo (Prague, 2006), p. 322 .

5 These archetypes of expression in the cycle of sonatas are referred to e.g. by Marta Ottlová. See Marta Ottlová, "Smetana a Dvořák na materiálu prvních vět posledních kvartetů" [Smetana and Dvořák on the Material of the First Movement in the Last Quartets], Hudební věda, 29 (1992), p. 110-117.

6 Figurative passages, however - in harmony with the period paradigm of composition - are not formed by the simple methods of scale or broken chords. The tone material of the passages draws upon various, usually artificially constructed modalities or decomposition of quartal chords with melodic tones, etc. 
melodic forms. The recapitulation preserves at least partly the extent and structure of the exposition with partial changes within each theme and between one another.

The principal theme (bars 1-10) is not a monolithic form without conflicts. " In a condensed form" it contains the elements and procedures typical of other, toccata parts of the composition. The vigorous initial gesture is found already in the dynamic introductory chord of the whole movement, combining the third and (perfect) fourth chord intervals with second condensation due to the use of tone from five-three chord $\mathrm{C}$ major and the dominant seventh chord G7. Its composition moreover acts as a condensed horizontal. This is continued by the passages of the constructed mode (with the scheme $1-2-2-1-2-2-1)^{8}$ and freely sequenced figures formed by phase-shifted seventh chords, to which second or third intervals were added. The lyric element is introduced by the half-tone waving melodised figuration, with a hint of quickly abandoned harmony $\mathrm{E}$ minor (bars 4-5).

The brief subordinate theme (Andante, bars 11-17) is prepared by the diminishing dynamics and textural simplification in bar 10. It preserves the uniform, non-conflict course in a mild tempo with a change in the metro (as well as the bar from $4 / 4$ to $3 / 8$ ), which creates the opposite pole to the moveable principal theme. Its evolution alternates with the contrasting lyrical area with moveable harmony in middle voices, while the melody pattern is (especially in the beginning) rather secondary, derived. A distinctive feature is produced especially by the vertical heaping of thirds with the arising bitonal procedures while incomplete thirteenth chords with varying chords (unlike the prevailing linearity of the principal theme). The motoric episode separating the subordinate and concluding themes, proceeds in bars 18-25.

\footnotetext{
7 As Lenka Dohnalová aptly says: "The principal theme appears in such a form that it gives the sonata the dynamics of the performed part, without the necessity of composing this dynamic character." In Lenka Dohnalová, Konstruktivistická metoda v Ježkově artificiální tvorbě [The Constructivist Method in Ježek's Classical Music] (Prague, Faculty of Philosophy of the Charles University in Prague, Diploma Thesis, 1982), p. 76.

8 Counted according to half-tone distances.
} 

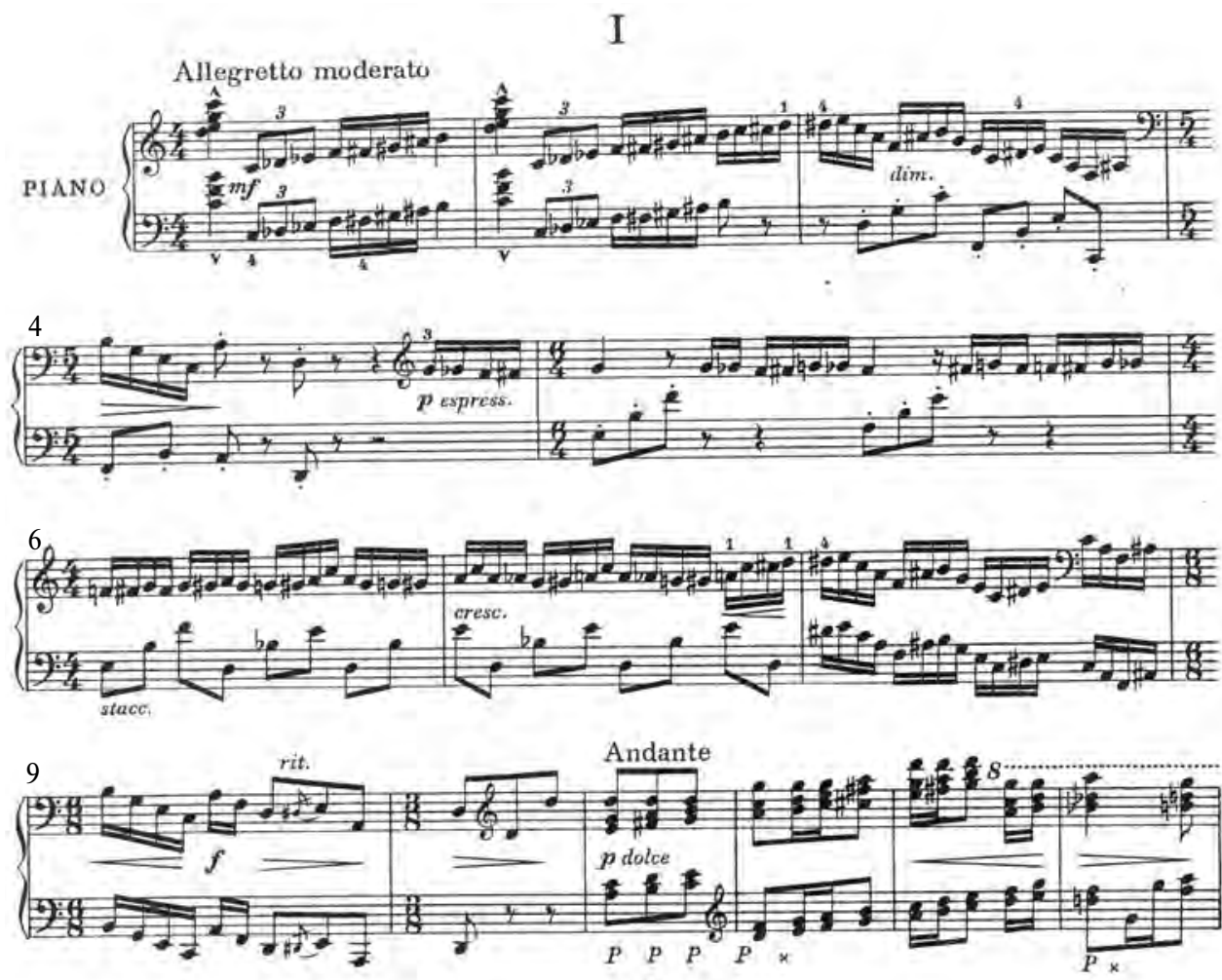

Allegro

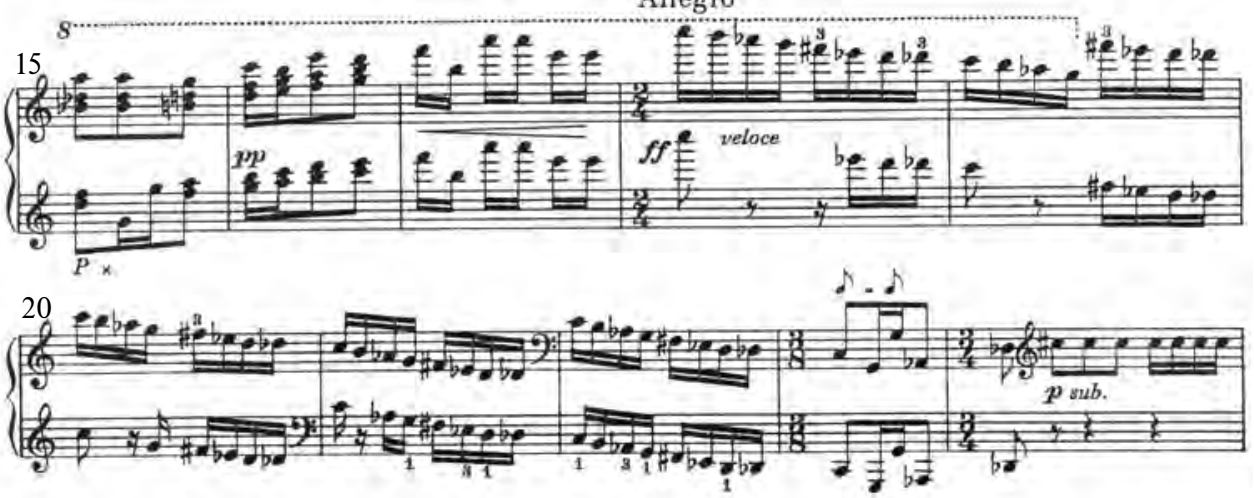

Example 1

The concluding theme (Meno, bars 26-37) introduces a cantabile expression into the first movement. ${ }^{9}$

9 To this corresponds the supple shaping of the melody arch, elements of periodicity, steps of the major and minor second, perfect fourths and minor thirds with a return to structurally important tones. 

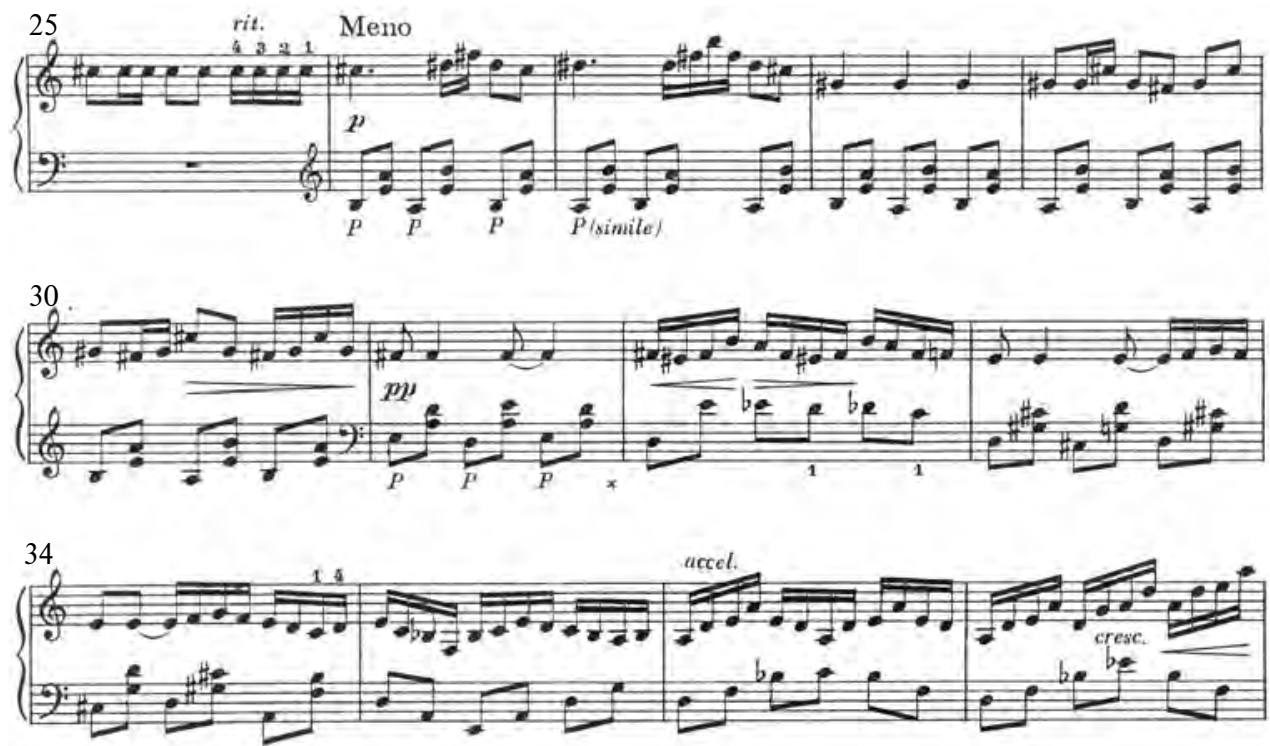

Example 2

It consists mainly from tones of the pentatonic series. Like the introductory figuration of the principal theme or the moveable middle voices of the subordinate theme, here at first the second procedures are developed. Already when the left hand starts, the intention is revealed of creating a dissonant conflict (major ninth), as it is in other places as well. The harmony arises rather "incidentally" as a vertical intersecting of the primarily linear procedures (the persisting ostinato movement of each figure in the left hand, with the receding of the outer tones by the interval of a major second). The concluding theme passes into the final part of the exposition (bars 38-52), within which the semiquaver figurations are detached (bars 46-52), followed by a variant of bars 3-4 in the principal theme, preparing a transformed subordinate theme with the concluding descent heading for the dynamic culmination of the exposition (bar 52), followed by the beginning of the development (bar 53).

From this it follows that evolutionary elements partly appear already in the exposition. The contrast between the principal theme and the two other themes is carried by a greater power than the contrast between exposition and development, comprised of two distinctive parts: the semiquaver passages (bars 53-90) and the area with the concluding theme (bars 90-115) with a transition to the recapitulation, in which the toccata motoric

The cantability of the melody, however, does not depend on diatonic techniques (with intervals of major and minor seconds, appearing as an element significant for expression e.g. in the $5^{\text {th }}$ bar in the main theme) but with pentatonic techniques. 
semiquaver stream of music reappears (bars $116-127) \cdot{ }^{10}$ The performance is based on contrasts between the motoric elements (variously stylized passages formed mainly by revolving figures with an interval jump subsequently filled with a gradual progress in a contrary motion) and the cantability of the varied concluding theme (bars 96-104), which leads to the development of complex blocks of music. In the distribution of the form there is the interesting placing of the melodic climax of the development in its first part (bar 89), while the recapitulation later proceeds from the figurative stream of semiquavers with a sudden dynamic increase (bar 127). The concluding theme - as a misleading repeat - begins unchanged (bars 105-110) but with a melodiously different final course and the subsequent figurative section.

The re-exposed beginning of the principal theme opens the recapitulation. As an important element of identification, the accentuated chord from the first bar re-appears. However, this is not a mere recapitulation of the exposition. Unlike in the exposition, the quick passages separating the individual thematic blocks are reduced for the sake of greater compactness (e.g. the re-exposed principal and secondary themes are separated by a single thus conceived bar). With this reduction of the episodes, a more coherent flow of music with lyrical areas (variants of the secondary theme) is achieved while the general dynamism diminishes.

The second movement (Tempo di polka - Moderato) is composed in a ternary form with the recapitulation of the scheme ABA (bars 1-72, 73-111, 112-183). Part A is com-

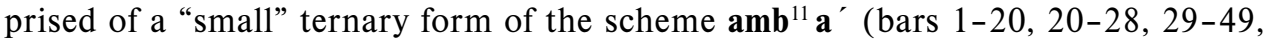
$50-72$ ). The parts are not strictly separate, rather they differ in texture and in dynamics. From this aspect part $\mathbf{b}$ is distinguished by thick chords, which alternate with motoric areas in unison of both hands and with more intensive dynamics. Part $\mathbf{B}$ can again be subdivided into three parts like a "small" ternary form aba' (bars 73-87, 88-103, 104-111). Part b contrasts with the two neighboring parts especially by its heavy melodic stylization of the polka elements (bars 92-103) like the analogical section in part A (bars 29-32). The outer parts can be characterized vaguely or by not clearly profiled melodic lines with a more distinct share of the melodisated, quasi improvised counterpoint in the left hand.

The distribution of the form with the middle part (trio) and a literal return Da capo preserves the typical formal scheme of a dance. The application of a stylized polka in the second scherzo movement can be seen as a sign of "making the expression more distinctly

10 From the aspect of the prevailing texture (realized by linear passages or by lyrical areas based on melody and harmony, that is with the division melody $\mathrm{x}$ accompaniment) in the performance also the principle of three parts is applied (bars 53-90, 90-115, 116-127), though of course with the shortened concluding part.

11 Considering the use of some elements of composition (semiquaver passages including intervalic, distinct accompaniment with chords on light times, etc.) from the middle movement in part $\mathbf{b}$ it is possible to say that in the ambivalent conception of form, part $\mathbf{b}$ already begins from bar 20 . 
Czech", ${ }^{12}$ due to the uneasy situation of the composer in his American exile. From the polka Ježek thus could use both the syntactic aspects (consisting in application of various elements of the polka) and the semantic aspects (the use of icons and indexes; moreover, polka is a symbol - of Czech music, the Czech nation).${ }^{13}$ The use itself of a stylized polka is an unusual element in a piano sonata. As a symbol of the link with Czech culture it was used by Zdeněk Fibich in his string quartets (A major, 1874) and (more intensively and with a concrete idea) by Bedřich Smetana (E minor " $Z$ mého života" [From My Life], 1876; D minor, 1883). Ježek, however, makes use only of some distinctive idioms (the division of the form in the manner of Da capo, the 2/4 meter; the polka-like accompaniment with the lightening of light times; typical metro-rhythmic schemes consisting especially in combinations of a quaver and two semi-quavers in quasi-folk freely sequenced parallel thirds, resembling persiflage phrasing, and contrasts in the alternation of staccato "secco" articulated areas and legato smoothed though rhythmically sharp melodic phrases). Unlike in the first movement, sharp contrasts between the areas are absent, due also to the gradual introduction of the elements typical of this genre. Especially the harmony, however, is a much individualized, progressive element. See the very first bars: the toccata stylized, staccato descent of two decomposed seventh chords on white keys (major seventh from $f$, minor seventh from $e$ ) is simultaneously confronted with the rising line (in the left hand), comprised of perfect fourths in simultaneous regular conflicts with seconds. ${ }^{14}$ The "two zones" in melodic harmony in the second bar are expressed by the right hand, stylized as a suggestion (G7-C) of the incomplete cadence on a metrically light time (with rhythmic vigor of the conclusion as one of the possible metro-rhythmic idioms of the genre). The movement of the left hand (modified scale), however, ends in the $c$ tone with a metric shift. (The jump $c-g$ on the turn of bars 2-3 is in the relation to the incomplete cadence in the $2^{\text {nd }}$ bar a retrograde step. At the beginning of the $3^{\text {rd }}$ bar thus very briefly sounds chord G7.)

12 Quoted after Jaroslav Jiránek in the quoted work Robert Smetana (ed.), Dějiny české hudební kultury 1890/1945, Part 2 (1918-1945) (Prague, 1981), p. 302. As Jiránek says next, the Nazi occupation in this country (in particular in piano composition) brought a simplification of sound and concentration of idea (see e.g. the cycle by Karel Janeček, Tema con variazioni), a return to romantic emotions and pathos (Sonata quasi Fantasia by Boleslav Vomáčka) or the Smetanesque genre stylizations (Tři poetické polky [Three Poetic Polkas] by Karel Boleslav Jirák, directly pointing to a cycle of the same name by Smetana).

13 On the polka intonations see Jiránek's semantic analysis of the polkas by Smetana in Jaroslav Jiránek, Hudebni sémantika a sémiotika [Semantics and Semiotics of Music] (Olomouc, 1995), p. 101-120.

14 When the distance between the two voices is disregarded. The characteristic clash is milder but dissonance is still preserved. 


\section{II}
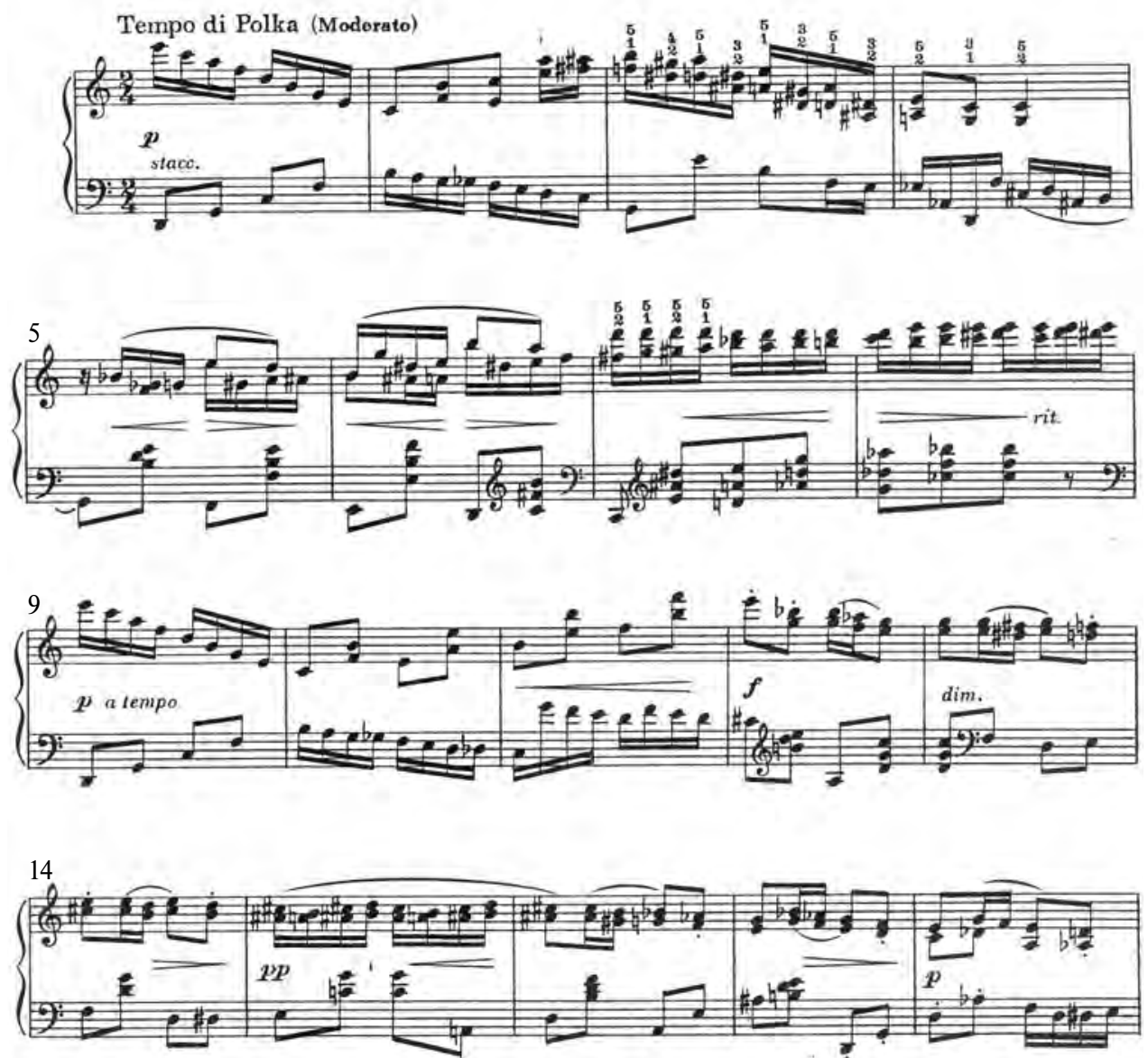

Example 3

The distinct polka idiom with the use of a stylized accompaniment with chords on light times (with intervals between bass and soprano) is clearly visible in bars 29-31. Here the extended chords (mostly thirteenth chords) are formed by accumulation of thirds on white keys like in the secondary theme of the first movement. On it are also loosely based the irregularly sequenced semiquaver passages, consisting in the phase shift of seventh chords on white keys (see bars 3-4 in the first movement and bars 34-38 in the second movement ${ }^{15}$ ), with an additional half-tone step. "The trio" (B), unlike the outer parts (with gradation in the conclusion), forms from the melodic, dynamic and textural aspect

15 For instance the descending broken seventh chords with the basic form $f-a-c-e, a-e-g-h$ (bars 37-38 in part $\mathbf{A}$ ) are applied in the $1^{\text {st }}$ movement (for the first time in bar 3). 
an ascending-descending area. Nor does it bring any new music. From the preceding (see bars 20-28 in part A) is taken over at first the polka-like phrasing in the right hand as well as ligatured quarter note, from which the movement of second intervals starts (bars 78-80, 88-91). A little extended variant of the clearly polka-stylized section form part A (from bars 29-31) forms the climax of the middle section of part B (bars 92-103).

The function of the whole with an important idea is given to the third movement (Lento). From this aspect it represents the central part of the composition. In the Sonata it is a part with a leisurely tempo and with an important idea and a contemplative course. The formal solution freely follows the three-part scheme aba' (bars 1-16, 17-53, 54-57) with a shortened and altered return, which like an arch frames the form. These parts do not have a clearly identifiable, concrete scheme. One can rather speak of the principle of passing, when from the introduction (e.g. the chords in the introductory three bars) new forms are crystallized, with a more distinct melody and a more varied style (in particular in section b, bars 23-31), which later return in some varieties. Unlike the preceding two movements, the harmony here is more often based on quartal chords, which, however, are often combined with tertian chords with frequent second clashes (including the false-relations). The third movement - because of its specific position inside the cycle - contains no distinct elements of a similar pattern noticeable in the first and second movements (descents of the thirds and quarters, the accumulation of the thirds in a vertical, and areas stylized like a toccata are in the outer parts). The mild tempo is not linked with the lyrical or cantabile element (as e.g. in the concluding theme in the first movement) but with stylization focused on ideas, and on the often texturally compact stylization. The more narrow melodic ambit of each multi-tone units, limited by their range, can be observed already in the first movement (less in the second movement with its varying height). Another example of the restriction of the melody bound to a particular interval model can be e.g. the (free) sequential shifts or transpositions of the finally stabilized in intervals or freely or in permutation altered tetrachord (e.g. in bars 11-13, part a). The introductory double bar of the third movement characteristically fills the melodically paralyzed progress of chords with moveable middle voices and later with ostinato returns to the forms already applied. (Likewise it was at the beginning of the subordinated theme of the first movement, where, however, interior second procedures take place within the chords composed from thirds only.) As a stabilized "ground" those chords function to which at the beginning of each section the action often returns. In bars 1-7 it is for instance the combination of a chord built in fifths ( $d-a-e$, left hand) and thirds ( $f-a-e$, right hand). 


\section{III}
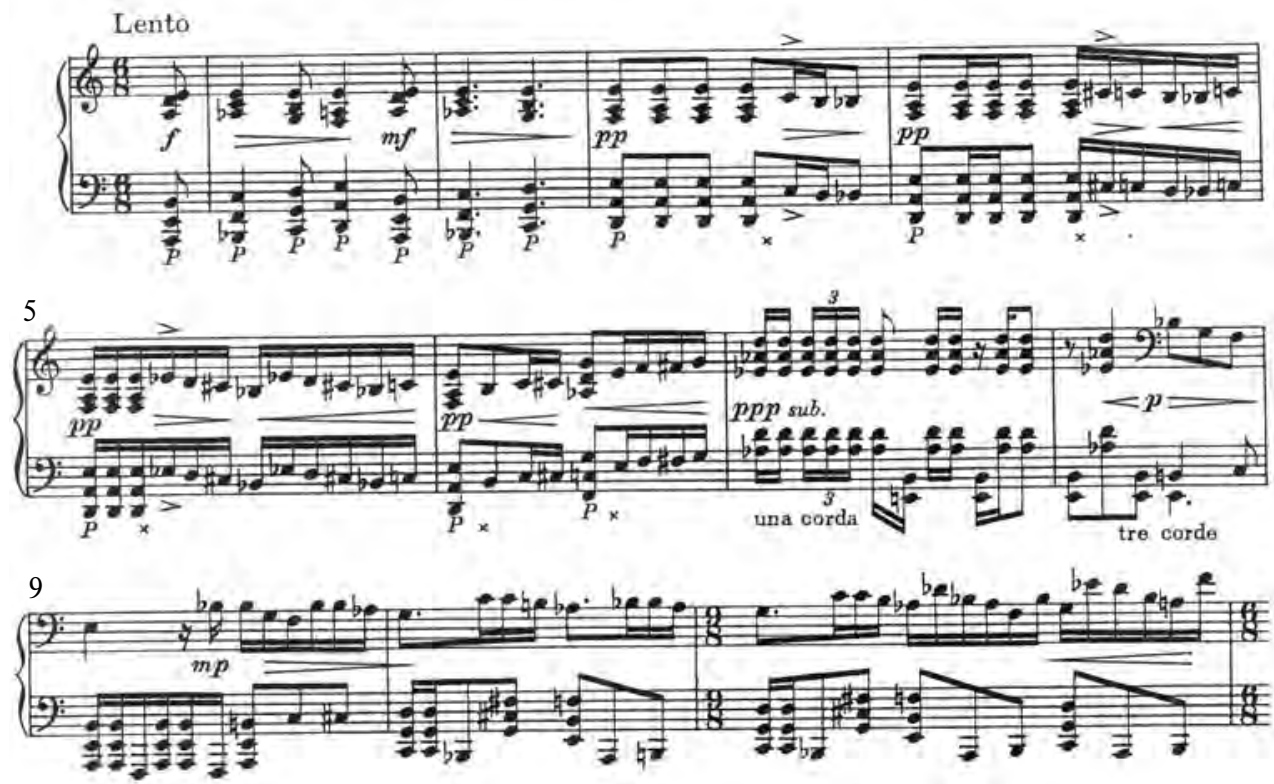

Example 4

The chord $c-g-d$ (for the first time used in the $10^{\text {th }}$ bar), produced again by countering two perfect fifths, is applied in the manner of the "bourdon" stylization in the irregular triplet vibration in the $17^{\text {th }}$ bar, with which part a culminates. In the next part (b) this chord appears at the beginning of some bars in the role of a stylizing point (centre), sometimes even with application of sound characteristics (the procedures referred to above, within the triplet pulse). This chord alternates with the broken five-three chord $\mathrm{G}$ major in the first time in the bar (first in bar 22), which with its frequent returns of the shifted motif helps to form an individual existence and distinctive quality (short and actually only introductory "shining" of the area by means of a tonally definite hint). 

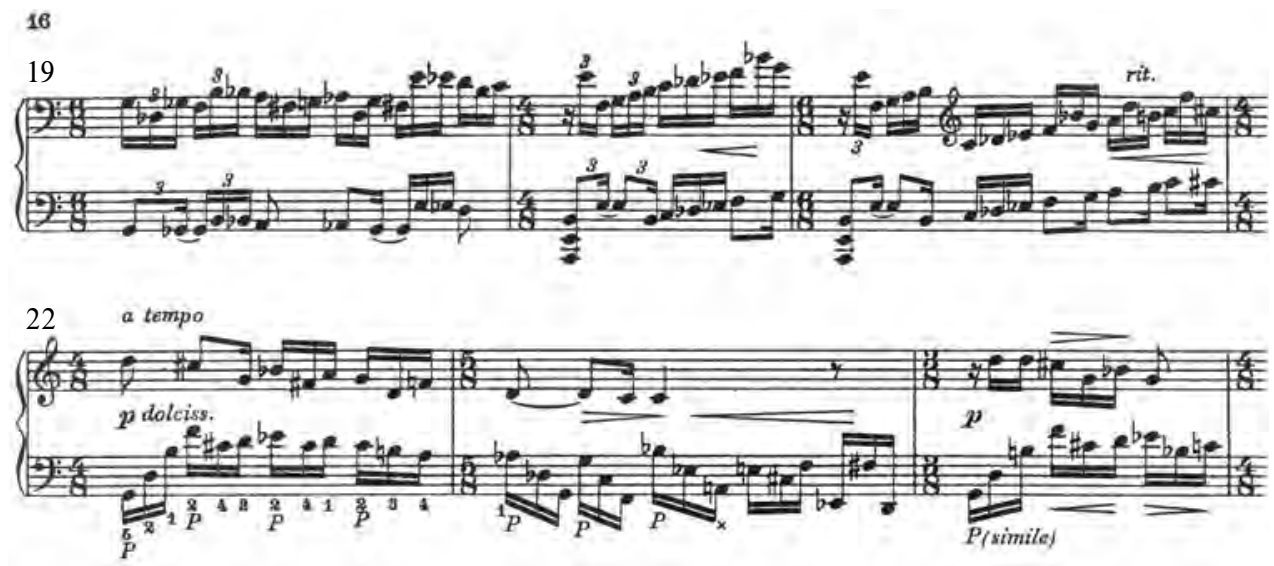

Example 5

The fourth movement is comprised of 298 bars. Its duration is also influenced by the fast tempo ${ }^{16}$ for the greater part of the movement, which proceeds mainly in the duple meter. The formal course is less clear than in the preceding movements, the pattern, however, contains elements of a variation rondo. An important principle of the organization of the macrostructure is the division into three parts (with Coda added), represented by the orientation scheme ABA' K (bars 1-164, 165-190, 191-258, 259-298). ${ }^{17}$ The proportion of bar representation of each part $164: 26^{18}: 68: 40$ bars. ${ }^{19}$ In favor of the modified tripartity speaks the distinct separation of part $\mathbf{B}$ from the outer parts. However, it can also be conceived as the extended episode (D) within the variation rondo with scheme $\mathbf{a b c a}^{\prime} \mathbf{c}^{\prime} \mathbf{b}^{\prime} \mathbf{a}^{\prime}$ ' $\mathbf{b}^{\prime}$ ' $\mathbf{D a} \mathbf{a}^{\prime}$ ' 'b' ' ' $\mathbf{c}^{\prime} \mathbf{k}_{\mathbf{a}}{ }^{20}$ In the parts with one mark, the motifs of the parts are modified especially by shapes with elementary melodic distinctions (e.g. repeated

16 Variations in the tempo follow the pattern in the macrostructure: Allegro (part A) - Pesante (part B) Tempo I-Vivo-Presto-Prestissimo (parts A' K). Already this scheme reveals the composer's intention to create the final movement with its tempo and dynamics gradually increasing, with a spectacular conclusion of the sonata cycle.

17 Capital letters refer to the compositeness of each part.

18 Included are the "transitional" sections in bars 165-166 and 187-191.

19 Real performance is of course influenced by the assumed slowing down of the tempo in part $\mathbf{B}$, which is rich in chords and concentrated on ideas as a single theme, and reversely, the gradually increasing tempo in the conclusion of part $\mathbf{A}^{\prime}$, continuing in the Coda.

20 Each small part can be also subdivided; for greater clarity, however, the division used in the further text is based on the main distinctive features, as they appear during the course of the movement: Part a - scherzo-decorated figure from the first bar, characteristic motif (disintegration of seventh chords) in the first bar of the second movement, the evolutionary stream of figurations starting from the repeated tones; part b - repeated tones, the quaver motif, "polka-like" stylized, taken from the second movement, part $\mathbf{c}$ - rhythmically sharpened idea proceeding in the double-stops of both hands. 
tones or semiquaver figuration, filled with the waving half-tone movement). Parts with two marks frame the whole area $\mathbf{A}$ with partial elements of the repeat (beginning of the modified part $\mathbf{a}$, adoption of music from the beginning of part $\mathbf{b}$ into part $\mathbf{b}^{\prime}$ ').

The first part (A) is characterized by the motor stream of prevailing semiquavers, rhythmically combined with quavers or quarters. According to the prevailing content they are divided into section of several bars, innerly connected. Due to the prevailing toccata stylization the boundaries are not strict. Still in the first part three distinct motif complexes with prevailing evolutionary content can be identified, which are later modified to a various degree. (Specificity or ability to be identified in the course of the movement is based especially in the introductory motifs, distinct in melody or rhythm.)
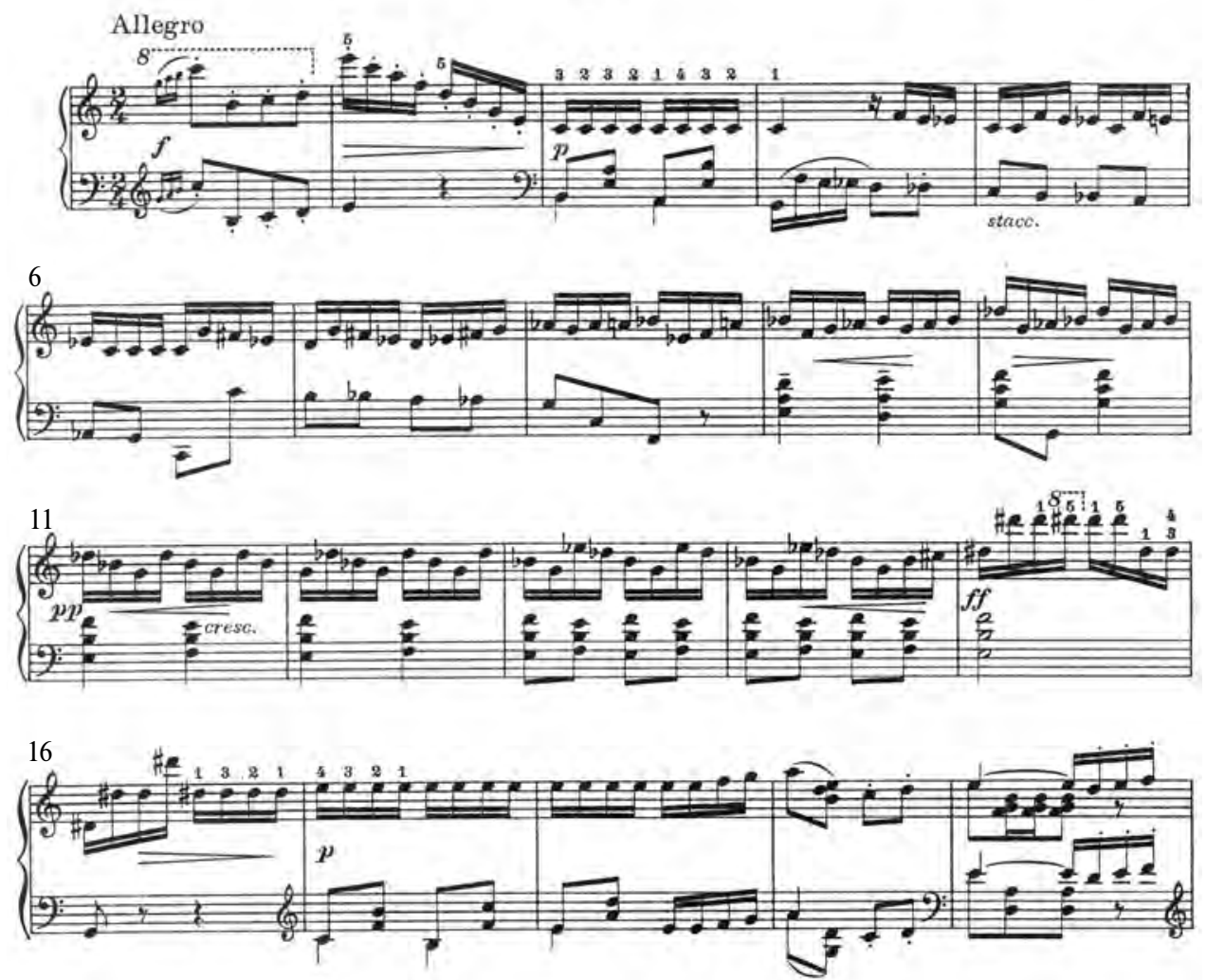

Example 6

The first of these units (a, bars 1-16) is contrasting in melody, based on the passages of seventh chords on white keys (while the $2^{\text {nd }}$ bar is identical with the $1^{\text {st }}$ bar of the second - scherzo - movement). This ends in a complex motif, with repeated tones at the 
beginning (bar 3). They appear in the second part as well (b, bars 17-50), to which the subsequent motif is added, the rhythmic pregnancy of which is based on the polka-like accompaniment (bar 20). (This procedure too refers to many sections in the $2^{\text {nd }}$ movement, starting with its $21^{\text {st }}$ bar.) The third part (c, bars 51-73) is distinguished by doublestops in either hand, with symmetrical expansion and compression of intervals, which are enlivened e.g. by a modification. ${ }^{21}$ This approach causes the binding of the melody to a particular rational structure.
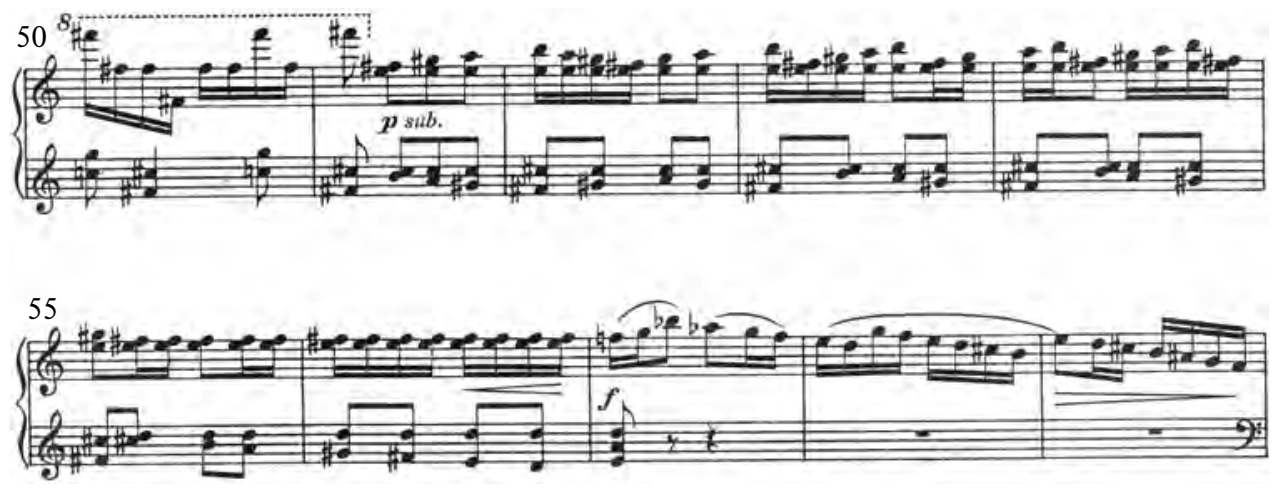

Example 7

A characteristic feature is the restriction to the tones of the lower pentachord from the tone series E major (in the right hand) and F sharp minor (left hand) in a five-finger position. In the next course of part $\mathbf{A}$ the motifs of the units referred to above are processed as variants with less sharp, more fluent transitions. One can also speak of fluent evolution, divided by melodiously distinct beginnings of initial motifs from each part.

The second "great" but much shorter part (B) contrasts with the preceding (and following) parts in its slowing down of motion and tempo (Pesante in bars 177-186) and the frequent position of chords or double-stops without the fast motion of semiquavers, typical of the previous part. It is built upon gradating variants of the opening section (bars 167-171). The character of the syncopated rhythmic double-stop link (bar 167), the transformations of which give rise to the following quartal chords, is determined already by the tritone distance between its upper voices (des, $g$ ), including the contrast of black and white keys. The sharpness of the sound, portending the character of part $\mathbf{B}$, is emphasized by the current $(d-d e s)$ as well as the subsequent false-relation $(a s-a)$. The final part $\left(\mathbf{A}^{\prime}\right)$ is quick, with semiquavers prevailing. From the aspect of motifs, the whole

21 E.g. in bar 52, in the right hand is applied the retrograde motion to the preceding model, while after the return to the initial tone the action is repeated (but starting with a partial lighter time, bar 52) with the omission of two double-stops and a different rhythm. In this way is achieved the effect of rearranging the elements, but this is limited by their restricted number and the rhythmically different but not quite systematic repetition, the beginning of which, moreover, is hidden and difficult to identify by hearing. 
form is thus framed by it. The motifs, in contrast to part $\mathbf{A}$, are varied, with emphasis on evolutionary mobility, with gradually increasing tempo, which culminates in the Coda. The rapidly changing course is mainly due to numerous changes in movement and internal compositions, often taking turn after tetrachords. The figuratively stylized melody pattern is close to similar sections in the first movement (step-like or revolving tetrachords with irregular intervals, free sequences or transpositions, etc.). However, unlike in the motoric areas of e.g. the Toccata or the Rhapsody, Ježek does not mechanically alternate tones on white and black keys, divided for both hands. In the considerably movable semiquaver passages, he makes use of numerous octave unisons (often contained constructed closed modes $^{22}$ with $1 \frac{1}{2}$ tone step and major third, ${ }^{23}$ see e.g. bars 246-247) as well as of quartal chords with the tritone in the left hand.

Among the elements securing cohesion of the (here the four-movement sonata) cycle are the interrelations between motifs or themes, the manner of their existence and the functions within the cycle. Ježek does not achieve the bonds between the movements in the Sonata by consistent monothematic cohesion - e.g. by working with a single opening motif (motifs) or adoption of whole sections or blocks of music from other movements. Only in the $2^{\text {nd }}$ bar in the concluding movement he quoted the opening bar of the second movement. Rather he applies suggestions or he works with a similar material but done differently: In the fourth movement, where among other things he evokes elements and procedures from the first two movements with a quick tempo, in bar 3 or bars 17-18 the motif of repeated tones appears. They occur in various places of the exposition as well as in the development in the first movement (in the repeat they were dropped to make speed up the course), in the role of a connection (here they serve as an element of stylization), separating those sections of music that are fairly important in their themes or motifs. In the fourth movement, because of its motifs (and a certain "emancipation" ${ }^{4}$ of the passage from the significant motif), they form repeated tones, to which are added sym-

22 After the terminology by Jaroslav Volek [konstruované uzavřené mody]. See below.

23 In the prevailing form 1-3-2-1-1-3-1 (with partial symmetry of the augmented second at the beginning and at the end, that is only "one step" separates it from complete symmetry). Jaroslav Volek in his study "Modalita a její formy z hlediska hudební teorie" [Modality and Its Forms from the Aspect of the Theory of Music], in: Jaroslav Volek, Struktura a osobnosti hudby [Structure and Personalities in Music] (Prague, 1988), p. 8-69, puts modes with augmented seconds in group A12 and does not classify them in greater detail. He points out that these modes generally sound "oriental" or refer to the Hispanic (M. de Falla) or "Gipsy" origin. The first trichord refers in passim to the Gipsy (major) scale, but the final tetrachord refers to the harmonic minor.

24 Variously styled, independent colorist figures are found in compositions of the first half of the $20^{\text {th }}$ century in particular in piano sonatas or concertos. See e.g. Concerto in D flat major No. 1 by Sergei Prokofiev (especially the performance of the first movement) or Sinfonietta giocosa by Bohuslav Martinů, where the final movement is formed by the toccata. See Jitka Ludvová, "Sonátová forma v klavírních koncertech Bohuslava Martinů" [The Sonata Form in Piano Concertos of Bohuslav Martinů], Hudební věda, 8 (1971), No. 3, p. 298-317. 
metrically expanding pianistic figures in the left hand (which accompany the concluding theme in the first movement), the initial little motif from which the stream of music rich in intervals develops. Among other adopted elements but with an altered melody is the in melody altered elements is the "polka-like" styled motif with a clear sixth chord core (bars 19-20), which forms one of the constituents of the transition linking parts a and $\mathbf{b}$ in the second movement.

\section{III.}

This description of Ježek's linear melody pattern and other components of music can be applied to the piano compositions written prior to the Sonata. Jiránek ${ }^{25}$ in this connection mentioned the fact that Ježek was obviously influenced by the options of piano stylization. His melody pattern in quick parts is based on virtuoso pianistic figures, in the composition of which often appear a second direct motion or a more distinctive head (e.g. fourth or fifth), subsequently filled with shorter steps in contrary motion. After the slower area (the third movement of the Sonata, part B of its final movement) rather comes the limitation e.g. by the seventh or ninth outlines (which arises e.g. by a counterposition of two fourths or fifths in a quartal chord) with free shifts of sequences or with transpositions. There also appears the ascending-descending shaping (e.g. in the subordinate theme of Sonatina), symmetrical expansion or compression or returns to identical intervals. In the first movement of the Sonata should be mentioned the melody of the subordinate and concluding theme as a penetration of the lyrical or cantabile element, not found in this form in the previous works of Ježek.

In compositions for the solo piano Ježek seldom makes use of polyrhythmic patterns (that would be e.g. the result of the concurrence of two bars metrically different). With Rhythm he emphasizes the relation between the melodic and the accompanying zones. In his compositions ostinato rhythmisized, "secco" accentuated quavers (e.g. "toccata" stylized areas in the Rhapsody or in the first and fourth movements of the Sonata) are frequent, emphasizing the stream of semiquaver passages. Thus it is possible to speak of the principle of the so-called motoric rhythm: While in the past a particular type of rhythm was primarily part of the accompaniment, in the work of the composers of the "modernism in music" of the first half of the $20^{\text {th }}$ century (Sergei Prokofiev, Béla Bartók, Paul Hindemith, Igor Stravinsky) "it became emancipated as a means semantically strengthening the expression of energy, vitality, the atmosphere of the world filled with technology, etc.; the condition here was regularity, ostinato, and precise maintaining of the metric pattern." ${ }^{26}$ The occasional perfusion or crossing of rhythmic configurations of the $2: 3$ cannot disrupt the beat of the duple meter. Ježek often applies syrrhythmic or homorhythmic stylization. Duple or triple meters are often underlined by the ostinato

25 Jaroslav Jiránek, Česká klavirní tvorba 1890-1945, Hudební věda, 4 (1967), No. 2, p. 283-284.

26 Jaroslav Volek, Jiři Vysloužil and Miroslav Karel Černý, "Rytmus” [Rhythm], in: Jiří Fukač and Jiří Vysloužil (eds.), Slovník české hudební kultury [Encyclopedia of Czech Music Culture] (Prague, 1997), col. 801-805. 
figure in bass (see e.g. the $1^{\text {st }}$ intermezzo or the March from the Petite suite ), above which a more rhythmic action goes on. The marching rhythm, which is a variant of the motoric rhythm, is found in Ježek for instance in the Rhapsody (Tempo di marcia) as well as in the first movement of the Sonata (with metrically firm figures, based on the alteration of quavers and semiquavers) in the manner of the rhythmization of the drum (repeated tone). Ježek often alternates bar patterns including the meter (e.g. in bars $42-50$ of the fourth movement of the Sonata the bars often change in the pattern: 2/4, 3/4, 2/4, 4/4, 2/4; also distinctly in the Etude, with alteration $6 / 8,5 / 8,4 / 8$ and $3 / 8$ bars), which reduces the stereotypic character of the passages in the octave unisono (Sonata), or which creates a type of melodic-rhythmic movement (Etude). To brighten up the motoric stream, Ježek often resorts to syncopation. E.g. in the part Oh, girls!.. from the Petite suite the metrically irregular left hand disturbs the duple meter (in 2/4). In the third movement of the Sonata the unequal length of the phrases corresponds to the frequent alteration of time. Another element significant for expression is the dotted rhythm, often used together with dissonant chords (e.g. the March from the Petite suite). In several cases the metro-rhythmic course (including the typical figures or procedures) is based on an inspiration by a genre (e.g. march, charleston, polka, minuet, nocturne).

In the analysis of Ježek's Sonata, as well as of other piano compositions, it is possible to point out the character of the vertical component. The many dissonant clashes (with half tones or whole tones, triton steps, etc. $)^{27}$ often occur already at the beginning of the action of the motifs due to the concurrence of two layers (in one of which for instance a doublestop or chord may be represented) with autonomous continuing motion. So for instance in the concluding theme of the first movement of the Sonata, in parallel with the melodic voice in the right hand (bar 26) tone $B$ sound in the left hand (and at the same time cis 2 in the right hand), from which the ostinato, "pendulum-like" symmetrical procedures of pianistic figures are developed (the combination of lower tones and double-stops gives rise to quartal chords) with sound dramaturgy, applying the polarity of white (left hand) and black keys (right hand). ${ }^{28}$ This motif element betraying the composer's intention, passes to the fourth movement of the Sonata (already in bar 3). Similar dissonant elements can be seen in the composition of the chords, too. Ježek works with tertian and quartal chords ${ }^{29}$ including their combinations (the free movement of the Sonata), alterations, thickening

27 Including greater distances than the octave. The dissonant clash farther away from the two voices, however, is usually not thought to be too sharp.

28 Sound dramaturgy of alternating tones on white and black keys is usually applied not only simultaneously in combinatory chords (see the March from Ježek's Petite suite, bar 7) but also used for differentiation of two sections (see e.g. bars 158-161 against 162-163 in the fourth movement of the Sonata), even in the "more" or "less" expository (bars 29-31 against 32-38 in the second movement of the Sonata).

29 In the Sonata third chords prevail in the "polka" movement (thus they refer top the genre source), fourth chords in the "toccata" final movement (with quick, by piano texture influenced alteration of fourth-fourth or fifth-fifth stylization in the left hand). The relation to fourth and third chords is approximately well-balanced in the whole composition. 
of seconds and expanded intervals. ${ }^{30}$ Often the extended chords appear, which arose by a rational accumulation of thirds (see the many areas of the Sonatina, $2^{\text {nd }}$ movement of the Sonata, etc.). Typically, Ježek makes no use of the five-three chord in a "perfect" form in the vertical cross section. Also the passages of the decomposed five-three chords or seventh chords are complicated by clashes with the left hand (e.g. bars 11-14, 65-69 in the fourth movements in the Sonata).

Ježek does not work on the basis of tonality with hierarchical relations, confirmed e.g. by cadences, modulations to the return of the tonal area, and the like. He only exceptionally resorts to the forming power of tonal (functional) relations. Moreover, they rather appear in suggestions and modifications. So e.g. in the recapitulation of the first movement of the Sonata (starting with bar 139) is strikingly often found a connection of two chords with elements of the dominant seventh chord G7 and the five-three chord C major. ${ }^{31}$

In many places Ježek applied the principle of tone centrality [tónová centralita]. This term was introduced into Czech theory of music by Alois Hába. ${ }^{32}$ According to him, at each level it is possible to create all kinds of harmony so that all its tones relate, on principle, to one central tone or tones. ${ }^{33}$ Hába thus fundamentally differentiates himself from Schoenberg's dodecaphony. (The principle of tone centrality was first applied in his Symfonická fantazie pro klavír a orchestr, op. 8 [Symphonic Fantasy for piano and orchestra] of 1921). Jiří Vysloužil ${ }^{34}$ points out that the conception of tone centrality appears in the work of many composers in the interwar modernism - e.g. Béla Bartók, Sergei Prokofiev, Paul Hindemith, Erwin Schulhoff, ${ }^{35}$ etc. The same applies for Ježek: The feeling of the tone center originates in one tone, double touch or chord, often repeated

30 The "agreeable stimulation" of the tritone and the "uniform, merging effect", evolved by the chord with a triton element is pointed out by Karel Janeček in his book Základy moderní harmonie [Essentials of Modern Harmony] (Prague, 1965), p. $50 \mathrm{ff}$.

31 The first chord contains parts of the dominant seventh chord (G7), when tone $g$ is part of the melody. Chromatic elements - tones cis, gis - are next developed into tones $d$, $a$. The soprano voice in this sinks to tone $e$, which can be identified as the third of fifth chord $\mathrm{C}$ major (with seconds added), which in the "pure" form appears in the left hand. Tone $a$, which appears at the same time and refers to chord A minor, is the outcome of quarter parallelism arising in chords of the analyzed section continuously between the inner voice. At the same time, however, an interpretation is possible of the chord in the right hand as fourth-second styled fourth chord.

32 See Alois Hába, Nová nauka o harmonii diatonické, chromatické, čtvrttónové, tretinotónové, šestinotónové a dvanáctinotónové soustavy [The New Discipline of Harmony in Diatonic, Four-tone, Six-tone and Twelve-tone Systems] (Jinočany, 2000).

33 See Jiří Vysloužil, “Tónová centralita” [Tone Centrality], in: Jiří Fukač and Jiří Vysloužil (eds.), Slovník české hudebni kultury (Prague, 1997), col. 942.

34 Ibid.

35 Markéta Kodedová in her diploma thesis Atonální klavírní cykly Ervína Schulhoffa [Atonal Piano Cycles of Erwin Schulhoff] (Olomouc, Faculty of Philosophy of the Palacký University in Olomouc, 2002) finds tone centrality (p. 58-59) even in many parts of the "atonal" cycles by Schulhoff (Zehn Klavierstücke, Elf Inventionen, Musik für Klavier in vier Teilen). They are e.g. a delay on a single tone or chord, most often in bass (that is like in Ježek), structurally important tone in the melody, etc. The 
(e.g. like a delay), especially in bass. E.g. in the $1^{\text {st }}$ intermezzo in the Petite suite the movement of fifth intervals mostly develops from tone cis. In the outer sections of the second (free) movement of the Sonatina this role is played by the ostinato returning double-stop $e-h$ (bars 1-3, 27-28, 42-45). In the outer sections of the Toccata the advance to tone $c$ functions as a frame for the whole form. In the Sonata, tone c can be pointed out as well. It appears as a part of the combination chord containing the five-three chord in $\mathrm{C}$ major in the upper part at the beginning of the first movement. On the other hand, the melody of the secondary theme temporarily stops at chord G 8/7 (bars 14-15) and in the concluding theme tones appear from the A major and $\mathrm{E}$ major fifth chords. Tone $c$ then appears as the basic tone of the passage descent (bars 18-23) and is further used even in variants of the principal theme. Five-three chord $\mathrm{C}$ major is part of the combinatory chord, which concludes the movement. Tone $c$ also terminates the outer parts of the second movement (stylized polka) and forms the central tone of the melody voice in the outer parts of the middle part. In the third movement one can point to the centrality of the combined chord $d-a-e+f-a-e$ (part $\mathbf{A}$ ), with which is connected the occurrence of tone $e$ at the beginning of some phrases. With tone $c$, the opening motif (a) in the fourth movements begins, which in a modified form appear at the beginning of the Coda. This tone is moreover already in the $3^{\text {rd }}$ bar repeated (like in bars $32-3476-85,90$ etc.). Also, with it the whole composition ends.

IV.

By his tending toward a matter-of-fact, unsentimental expression, Jaroslav Ježek joined the stream of European modernism, represented for instance by Béla Bartók, Paul Hindemith, Igor Stravinsky, as well as now lesser known Ernest Toch. Like these and other composers (in this country e.g. Erwin Schulhoff, Karel Reiner, Gideon Klein, ${ }^{36}$ and during his career as a composer also Pavel Bořkovec), Ježek achieved this without the support of tonal harmony, nor did he accept Schoenbergian dodecaphony. The existence of tone centers shows his inclination to the centric hierarchy [centrická hierarchie]. Among his most characteristic compositions are his works for the piano, a sphere particular close to him as a pianist. Each idea in his music tells of his link with this instrument. In contrast to the piano compositions of e.g. Erwin Schulhoff and Bohuslav Martinů, Ježek's style of composition is not distinguished by such variety of melody, harmony or texture. He is a little "one-sided" composer, often bound to a particular "construction" pattern, e.g. in the frequent density of chords, symmetrical suppression or augmentation of intervals, accumulation of thirds in a vertical, and the like. (See e.g. the contrasts of tonal and modal areas in the piano concertos of Bohuslav Martinů, the acoustic ingenuity connected with the expansion of techniques in composition and expression in Erwin Schulhoff, or the synthesis of various stylistic stimuli in both of them.) Among the piano compositions by

principle of tone centrality is then one of the elements of integration in the form (like e.g. motivic integration).

36 The composers prominent in works for the piano. 
Ježek one can trace an increasing tendency to ward unity and seriousness of the music, which culminates in the last work he finished, the piano Sonata, in which he incorporated also lyrical or cantabile areas. The different solution of composition in Ježek's days (return to the pre-Classicist models, rational structuring, interlinking of the "new" and the "traditional", effort at a new type of expression) was brought about by the many problems caused by the breakup or weakening of traditional syntactic bonds (texture) connected with the functioning of tonality. Ježek's work is also a response of a kind, in line with the efforts of composers in the first half of the $20^{\text {th }}$ century.

Translated by Jaroslav Peprník

\section{Sonate von Jaroslav Ježek im Kontext der Klavierwerke des Autors}

\section{Zusammenfassung}

Den Inhalt dieses Artikels bildet eine Analyse der Sonate für Klavier, eines Werkes auf dem Höhepunkt des Schaffens von Jaroslav Ježek (1906-1942), die zwischen den Jahren 1939 und 1941 in der Zeit des Exils des Autors in Amerika entstanden ist. In den bisherigen Erwähnungen in der Fachliteratur wird dieses Werk nicht nur im Rahmen des bisherigen Euvres des Autors, sondern auch in Bezug auf die tschechische Musik der ersten Hälfte des 20. Jahrhunderts als einzigartig bezeichnet. Die Bedeutung der Sonate besteht vor allem darin, dass der Autor die Kompositionsvorgänge in ein viersätziges Ganzes integrierte, wie man es schon aus seinen vorherigen, insbesondere für Klavier komponierten Werken kannte. Es handelt sich zum Beispiel um die Bildung von Kompaktflächen auf der Basis eines in „Toccato“ stilisierten Stroms von Figurationen, eine charakteristische rational-konstruktive Schichtung von Akkorden (zum Beispiel nach Tertien-Intervallen und gleichzeitig auf Tönen von weißen Tasten), die Kombination vom Zusammenklang des Tertien- und Quarten- Aufbaus, melodisch-rhythmische ostinate Flächen usw. Der Charakter der Sonate wird auch von kantablen oder lyrischen Flächen mitgestaltet, was unter anderem auch mit der Unterscheidung einzelner thematischer Ganzen in dem ersten Satz des Sonatenzyklus zusammenhängt. Ježek arbeitete nicht auf der Basis der tonalen Harmonie, er neigte jedoch auch nicht zu Schönbergs Dodekaphonie. Die Existenz von Tonzentren (im Sinne der Terminologie von Alois Hába) lässt die Tendenz zur zentrischen Hierarchie verspüren. Diese Vorgänge hängen mit zeitgenössischen Bemühungen um eine sachliche, nicht sentimentale musikalische Darlegung zusammen. 


\title{
Sonáta Jaroslava Ježka v kontextu autorova klavírního díla
}

\begin{abstract}
Shrnutí
Obsahem této stati je analýza klavírní Sonáty, vrcholného díla Jaroslava Ježka (1906-1942), vzniklého mezi lety 1939-1941 v době skladatelova amerického exilu. Dosavadní zmínky v literatuře pokládají toto dílo za jedinečné nejen v oblasti skladatelovy dosavadní tvorby, ale i české hudby první poloviny 20. století. Jeho význam spočívá zejména v tom, že autor do čtyřvětého celku integroval kompoziční postupy, pozorované již v jeho předcházejících, zejména klavírních skladbách. Je to např. vytváření kompaktních ploch na bázi „toccatově“ stylizovaného proudu figurací, charakteristické racionálně konstrukční vrstvení akordů (např. po terciových intervalech a zároveň na tónech bílých kláves), horizontální i vertikální kombinace souzvuků terciové a kvartové stavby, melodicko rytmicky ostinátní plochy apod. Charakter Sonáty vytvářejí také kantabilní či lyrické plochy, což souvisí mimo jiné s odlišením jednotlivých tematických celků v první větě sonátového cyklu. Ježek nepracoval na bázi tonální harmonie, nepřiklonil se však ani k schönbergovské dodekafonii. Existence tónových center (ve smyslu terminologie Aloise Háby) prozrazuje inklinaci k centrické hierarchii. Tyto postupy souvisí s dobovým úsilím o věcný, nesentimentální hudební projev.
\end{abstract}

\section{Keywords}

Jaroslav Ježek (1906-1942); piano works; piano Sonata; music analysis. 